\title{
LA PRIMERA CONTRIBUCIÓN DE LOS OBISPOS ESPAÑOLES A LA CODIFICACIÓN DEL DERECHO CANÓNICO DE 1917: LOS POSTULATA DE LOS METROPOLITANOS ESPAÑOLES*
}

\author{
POR \\ CARLos SALINAS ARANEDA ${ }^{1}$ \\ Pontificia Universidad Católica de Valparaíso, Chile
}

\begin{abstract}
RESUMEN
La redacción del primer Código de Derecho Canónico que tuvo la Iglesia latina fue ordenada por el papa Pío X en 1904. La tarea codificadora, empero, no fue obra de un grupo cerrado de expertos, sino que tuvo en cuenta el parecer del episcopado, el que fue consultado en dos momentos diferentes; en ambos fueron consultados los obispos españoles. En este trabajo se estudia, a partir de la documentación guardada en el Archivo Secreto Vaticano, el aporte de los metropolitanos españoles en respuesta de la primera consulta, realizada en 1904.
\end{abstract}

PalABRAS ClAVE: Derecho Canónico; Código de Derecho Canónico de 1917; Metropolitanos de España; postulata episcoporum.

\section{THE FIRST CONTRIBUTION OF SPANISH BISHOPS TO THE CODIFICATION OF CANON LAW OF 1917: THE POSTULATA OF SPANISH METROPOLITANS}

\begin{abstract}
The drafting of the first Code of Canon Law of the Latin Catholic Church was ordered by Pope Pius X in 1904. The code was not made by a close group of experts, but considered the opinion of the whole episcopate. Such an opinion was consulted in two different moments. In both, the opinion of Spanish bishops was asked. The contribution of Spanish metropolitans to the first query in 1904, is studied in this work. The documentation was obtained from the Vatican Secret Archives.
\end{abstract}

KEY WORDS: Canon Law; Code of Canon Law 1917; Spanish Metropolitans; postulata episcoporum.

Cómo CITAR ESTE ARTículo / CitATION: Salinas Araneda, Carlos. 2020. «La primera contribución de los obispos españoles a la codificación del derecho canónico de 1917: los postulata de los Metropolitanos Españoles». Hispania Sacra LXXII, 145: $291-305$. https://doi.org/10.3989/hs.2020.022

$\begin{array}{lr}\text { Recibido/Received } & \text { 09-07-2018 } \\ \text { Aceptado/Accepted } & 25-10-2018\end{array}$

Al iniciarse en 1904 las tareas que llevaron a la confección del primer Código de Derecho Canónico que ha tenido la Iglesia, el que se promulgó en 1917 por Benedicto XV (1914-

* Este trabajo forma parte del proyecto de investigación regular del Fondo Nacional de Investigación Científica y Tecnológica -Fondecyt- de Chile, no 1160298, del que el autor es el investigador responsable, titulado «El aporte de los obispos españoles a la codificación del derecho canónico de 1917. Estudio dogmático y comparado».

1 carlos.salinas@pucv.cl /

ORCID iD: https://orcid.org/0000-0003-2070-7751
1922), ${ }^{2}$ se hizo una consulta a todo el episcopado latino, ocasión en la que fueron consultados los obispos de España, a fin de que expusieran las reformas que considerasen necesario introducir al derecho canónico vigente. Desde España llegaron a Roma las propuestas elaboradas en conjunto por los metropolitanos españoles, además de las particulares de los arzobispados de Burgos y de Tarragona. En las páginas que siguen centro mi atención en las reformas que se postularon conjuntamente por los metropolitanos españoles.

\footnotetext{
${ }^{2}$ Benedicto XV 1917, 5-8
} 


\section{LA PRIMERA CODIFICACIÓN DEL DERECHO CANÓNICO}

\section{La necesidad de fijar el derecho canónico}

Durante el segundo milenio, el derecho de la Iglesia estuvo contenido principalmente en el Corpus luris Canonici, un amplio texto integrado por cinco colecciones, la primera de las cuales fue el Decreto de Graciano (1140) seguido por las Decretales, de Gregorio IX (1234), el más importante de los textos canónicos de dicho Corpus; el Liber sextus, de Bonifacio VIII (1298); las Clementinas, (1317); las Extravagantes comunes y las Extravagantes de Juan XXII, colecciones menores elaboradas en el siglo XVI por el jurista parisino Jean Chapius. ${ }^{3}$ En la medida que fue pasando el tiempo, se fue elaborando una abundante legislación complementaria, extravagante al Corpus, que venía a satisfacer las necesidades que iban originando las nuevas realidades históricas que la Iglesia debía enfrentar, de manera que, en pleno siglo XIX, el conocimiento del derecho de la Iglesia y su aplicación se hacían en extremo difícil. Un postulatum de once obispos franceses durante el Concilio Vaticano I (1869-1870) ${ }^{4}$ ponía en evidencia que desde hacía tiempo que era evidente y reconocido que era necesario y muy urgente un examen y una refundición del derecho canónico, porque, como consecuencia de los grandes y numerosos cambios sobrevenidos en las circunstancias y en la sociedad humana, muchas leyes habían llegado a ser inútiles o inaplicables o muy difíciles de observar. Y después de constatar el aumento de la legislación eclesiástica, expresaban, de una manera bastante gráfica, que «podemos decir que estamos aplastados por las leyes». No fueron los únicos, pues otros obispos se manifestaron en el mismo sentido, ${ }^{5}$ discusión que se producía en el seno de la Iglesia cuando en el derecho de los Estados había triunfado una nueva manera de fijar el derecho: la codificación iusracionalista. ${ }^{6}$

La elaboración de un Codex luris Canonici que sustituyera al Corpus fue iniciada por Pío X (1903-1914) a poco de haber iniciado su pontificado en los albores del siglo XX. ${ }^{7}$ Lo hizo mediante el motu proprio Arduum sane munus, de 19 de marzo de $1904,{ }^{8}$ mediante el cual creó una comisión pontificia encargada de asumir la codificación del derecho

3 El Corpus luris Canonici fue objeto de una edición oficial en 1582, a cargo de una comisión romana cuyos miembros fueron llamados 'correctores romanos', edición que no recoge la denominación de Corpus luris Canonici, la que sí aparece en la de Lyon de 1671 y en las posteriores. La edición hoy utilizada habitualmente es la de A. E. Friedberg, 1879: Lipsiae; 1959; Graz. Con posterioridad, el Corpus fue complementado incorporándose en diversas épocas otros elementos, algunos de los cuales solo en ediciones privadas.

4 Mansi 1927, col. 341-342.

5 Además de la intervención señalada en la nota anterior, fueron los postulados suscritos por 37 obispos napolitanos, ibídem., col. 378-456, esp. 449-450; 15 obispos alemanes, ibídem., col. 352-378, esp. 355; el episcopado belga, ibídem., col. 456-461, esp. 460-461; 33 padres de diversas naciones, ibídem., col. 478-479; los obispos de las provincias eclesiásticas de Quebec y Halifax, ibídem., col. 467; y un grupo de prelados de Italia central, ibídem., col. 552-553.

6 Una reciente y completa síntesis sobre la codificación como modo de fijar el derecho de los Estados, en Guzmán 2005.

7 Para la historia de la codificación canónica de 1917 es imprescindible Fantappiè 2008 y algunos de sus trabajos posteriores 2011, 2017(b), 2018. Pueden consultarse también las actas de congreso publicadas por Baura, Álvarez de las Asturias y Sol 2017, y los trabajos de Baura 2017, Gómez-Iglesias 2017(a) 2017(b), Lo Castro 2017.

8 Pio X 1904, 549-551. de la Iglesia. El mismo motu proprio dispuso la intervención en esta obra de todo el episcopado latino, ${ }^{9}$ la que se puso en práctica mediante la circular Pergratum mihi, de la Secretaría de Estado, de fecha 25 de marzo de 1904, enviada a todos los metropolitanos. ${ }^{10}$ En ella se pedía que los arzobispos, oyendo previamente a sus obispos sufragáneos y otros ordinarios que debían estar presente en el concilio provincial, enviaren a la Santa Sede, dentro de los cuatro meses siguientes, en pocas palabras, las principales modificaciones y correcciones que debían hacerse al derecho canónico en vigor. En la misma circular se indicaba que era deseo formal del papa ver a todo el episcopado concurrir y tomar parte activa en un asunto que interesaba en grado máximo el bien y utilidad de toda la Iglesia católica. Detrás de esta segunda decisión se puede ver el interés del papa de que participaran en la nueva fijación del derecho de la Iglesia, no solo especialistas en cánones o en teología, sino que también los hombres prácticos que cotidianamente debían trabajar con los cánones en el gobierno de sus iglesias particulares. ${ }^{11} \mathrm{La}$ respuesta de los obispos de la Iglesia latina fue amplia, contándose entre ellas la de los obispos españoles.

El numeroso material reunido fue sistematizado según el índice de materias del futuro código, definido por los cardenales mientras se hacía la consulta, y recogido en un volumen que permaneció inédito, bajo la dirección del consultor Bernardino Klumper, con el título Postulata Episcoporum in ordinem digesta. ${ }^{12}$ Como ha sido puesto de relieve, ${ }^{13}$ estos postulata reflejan el sentir del episcopado mundial en lo que se refiere a la codificación y permiten conocer cuáles eran las preocupaciones y los problemas que interesaban al episcopado mundial a los inicios del siglo $\mathrm{XX}$, no solo de orden jurídico, sino también eclesiológico, disciplinar, pastoral, etc.; desde esta perspectiva, los postulata constituyen una útil manera de aproximarse a las realidades de las iglesias locales de la época a partir de unos protagonistas tan directos como eran los obispos de cada una de ellas. En ellos se solicitaron soluciones que, en no pocos casos, solo fueron adoptadas por el Concilio Vaticano II y el Código de Derecho Canónico de 1983. ${ }^{14}$

9 En la decisión cuarta, el papa manifestaba su deseo de que todo el episcopado, conformándose a las reglas que serían dadas en tiempo oportuno, colaboraran y concurrieran a esta obra tan importante: «IV. Volumus autem universum episcopatum, iuxta normas opportune tradendas, in gravissimum hoc opus conspirare atque concurrere».

10 Secretaría 1903-1904, 603-604.

11 Vetulani 1942 III, col. 920.

12 Codex luris Canonici/ Postulata Episcoporum/ in ordinem digesta/ a/ Rmo. P. Bernardino Klumper O. F. M./Consultore/ Romae/ Typis Vaticanis/ 1905/ 283 pp. Archivio, scat. 4. Posteriormente se agregó un segundo volumen, más breve que el anterior, con solo 68 páginas, impreso en 1908 con el título Appendix ad Postulata Episcoporum, reproducido igualmente por Bernardino Klumper en el que se recogen, probablemente, las respuestas llegadas con retraso, cuando el primero de estos volúmenes ya estaba en prensa. Este segundo volumen ibídem., scat. 6. Al no estar todavía generalizado el uso de la máquina de escribir, la mayoría de los postulata son manuscritos, lo que dificulta su lectura, a lo que hay que agregar el que ellos están escritos en diversas lenguas, porque no todos los obispos usaron el latín para sus respuestas, si bien un número importante usó la lengua oficial de la Iglesia.

13 Llobell, De León, Navarrete 1999, 47-48.

14 Otra circular, esta vez de 6 de abril de 1904, atribuible al secretario de la Comisión Pedro Gasparri, fue dirigida a los rectores de las universidades católicas para pedirles el concurso «en esta empresa importante y difícil». Gasparri 1904-1905, 130-131. 


\section{Los metropolitanos españoles}

Al momento de iniciarse la codificación canónica, la Iglesia en España estaba organizada en nueve sedes metropolitanas, al frente de las cuales se encontraban los arzobispos que indico en cada caso: Burgos, ${ }^{15}$ cuyo arzobispo era Gregorio María Aguirre y García OFM; ${ }^{16}$ Compostela, ${ }^{17}$ con el cardenal José María Martín de Herrera y de la Iglesia; ${ }^{18}$ Granada, ${ }^{19}$ con José Moreno y Mazón; ${ }^{20}$ Zaragoza, ${ }^{21}$ con Juan Soldevilla y Romero; ${ }^{22}$ Sevilla, ${ }^{23}$ con Marcelo Spinola y Maestre; ${ }^{24}$ Tarragona, ${ }^{25}$ con Tomás Costa y Fornaguera; ${ }^{26}$ Toledo, $^{27}$ con el cardenal Ciriaco María Sancha y Hervás, patriarca de las Indias Occidentales; ${ }^{28}$ Valladolid, ${ }^{29}$ con José María Cos y Macho; ${ }^{30}$ y Valencia, ${ }^{31}$ arzobispado que, al tiempo de la consulta, estaba vacante. ${ }^{32}$

\footnotetext{
15 Obispados sufragáneos: Calahorra y Calzada, León, Osma, Palencia, Santander, Vitoria.

16 Nacido en Pola de Gordón (León), diócesis de Oviedo, el 12 de marzo de 1835 . Preconizado a Lugo, el 27 de marzo de 1885 y promovido al arzobispado de Burgos el 21 de mayo de 1894.

17 Obispados sufragáneos: Lugo, Mondoñedo, Orense, Oviedo, Tuy.

18 Nacido en Aldeadávila de la Rivera, diócesis de Salamanca, el 26 de agosto de 1835. Preconizado al arzobispo de Santiago de Cuba, e 5 de julio de 1875. Trasladado a Compostela el 14 de febrero de 1889.

${ }_{19}$ Obispados sufragáneos: Almería, Cartagena, Guadit, Jaén, Málaga.
}

20 Nacido en Málaga, el 4 de diciembre 1825. Preconizado a Cuenca el 20 de marzo de 1877. Promovido a patriarca de las Indias Occidentales, el 18 de noviembre de 1881. Trasladado a Granada, e 27 de marzo de 1885.

${ }^{21}$ Obispados sufragáneos: Barbastro, Huesca, Jaca, Pamplona y Tudela, Tarazona, Teruel.

22 Nacido en Fuente la Peña, diócesis de Zamora, el 20 de octubre de 1843. Preconizado a Tarazona, el 14 de febrero de 1889. Promovido a Zaragoza el 16 de diciembre de 1901.

23 Obispados sufragáneos: Badajoz, Cádice, Córdoba, Canarias.

24 Nacido en San Fernando, diócesis de Cádiz, el 14 de enero de 1835. Preconizado a la iglesia titular de Milo, el 16 de diciembre de 1880. Trasladado a Coria, el 10 de noviembre de 1884. Trasladado a Málaga, el 10 de junio de 1886. Promovido a Sevilla el 2 de diciembre de 1895. Fue beatificado por Juan Pablo II el 29 de marzo de 1987.

${ }^{25}$ Obispados sufragáneos: Barcelona, Gerona, Lerida, Solsona, Tortosa, Urgel, Vich.

26 Nacido en Castella, diócesis de Gerona, el 6 de junio de 1831. Preconizado a Lérida, el 23 de septiembre de 1875. Promovido a Tarragona el 27 de mayo de 1889.

27 Obispados sufragáneos: Coria, Cuenca, Madrid-Alcalá, Plasencia, Sigüenza.

28 Nació el 17 junio 1833. Preconizado obispo titular de Areopolis y auxiliar del arzobispado de Toledo el 28 enero 1876 . Nombrado obispo de Ávila a fines de 1882. Trasladado al obispado de Madrid e 10 junio 1886. Promovido al arzobispado de Valencia el 11 julio 1892 Fue creado cardenal presbítero de San Pedro en Montorio el 18 mayo 1894. Trasladado al arzobispado de Toledo el 24 marzo 1898, la misma fecha en que fue nombrado patriarca de las Indias Occidentales. Fue beatificado por decisión de Benedicto XVI el 18 de octubre de 2009.

${ }^{29}$ Obispados sufragáneos: Astorga, Ávila, Ciudad Rodrigo, Salamanca, Segovia, Zamora.

${ }^{30}$ Nacido en Terau y Solones, diócesis Santander, el 6 agosto 1838. Preconizado a Mondoñedo, 10 junio 1886. Promovido a Santiago de Cuba, 14 febrero 1889. Trasladado a Madrid, 11 junio 1892. Trasladado a Valladolid, el 18 abril 1901.

31 Obispados sufragáneos: Mallorca e Ibiza, Menorca, Orihuela, Segorbe.

${ }^{32}$ El 9 diciembre 1903 había fallecido el arzobispo Sebastián Herrero y Espinosa de los Monteros y su sucesor, Bernardino Nogaleda y Villa op., fue nombrado el 14 noviembre 1904, cuando el plazo para responder a Roma ya estaba vencido.

\section{LOS POSTULATA DE LOS METROPOLITANOS ESPAÑOLES}

El informe de los metropolitanos españoles fue enviado por el cardenal Ciriaco María Sancha y Hervás, arzobispo de Toledo, $^{33}$ el que, fue remitido en el plazo fijado por Roma. Se trataba de diez páginas impresas - pagellis las llamaba el cardenal- que contenían 56 propuestas escritas en latín, todas ellas numeradas correlativamente, sin subtítulos separadores de las materias abordadas en ellas, si bien no es difícil advertir que el orden que se ha dado a las mismas es el de los cinco libros de los decretales de Gregorio IX, libros que tampoco llevaban un título propio, pero cuyos contenidos, para una más fácil recordación, se resumían en el verso latino: «iudex, iudicium, clerus, connubia, crimina», ${ }^{34}$ que es el que sigo al exponer brevemente los postulata hispanos. ${ }^{35}$

\section{LIBRO I: IUDEX}

El primero de los libros de las Decretales trata de los jueces eclesiásticos y de los prelados, pero los primeros títulos, después del primero, "De summa Trinitate et fide catholica», se dedican a las fuentes del derecho, por lo que las primeras propuestas españolas se refieren a ellas.

\section{Fuentes del derecho}

i) Divulgación de las decisiones de las Sagradas Congregaciones: la primera de las 56 propuestas arribadas a Roma desde España se refería a las decisiones o decretos que emanaban las Sagradas Congregaciones, respecto de las cuales los prelados solicitaban que se declarare legítimamente que, cualquiera que fuese la autoridad de las decisiones de las Sagradas Congregaciones, estas decisiones obligaren a todas las personas $y$, puesto que obligaban en general, debía hacerse público el decreto. Además, para que la ley o precepto fuere promulgado debidamente y constare su legitimidad, debían divulgarse, como era uso en las curias diocesanas españolas, en una hoja o periódico oficial por medio del cual se hiciere evidente tal obligación (I).

ii) Reglas sobre subrepción y obrepción: las reglas respecto de la subrepción y la obrepción debían ser más claras en la medida en que pudiere hacerse (II).

iii) Costumbre: había que delimitar el tiempo por el cual la costumbre adquiere fuerza de ley $y$, al mismo tiempo, tenían que ser delimitadas la fuerza, el valor y las condiciones de la cláusula que hacía nulas las costumbres futuras contra cualquier ley (III).

\section{Primados, metropolitanos y obispos}

i) Facultades de primados, metropolitanos y obispos en sus relaciones recíprocas: sugerían los metropolitanos que era totalmente conveniente, para la unidad del régimen eclesiástico, enfatizar y distinguir con suma claridad las facultades de los primados, de los metropolitanos y de

\footnotetext{
33 Con carta de 20 julio 1904. Archivio, scat. 84.

34 Del Paso 1874, I, 322; Juseu 1899, 61.

35 En cada caso, con guarismos romanos, específico el número de orden del respectivo postulatum.
} 
los obispos en sus relaciones recíprocas y, asimismo, regular aquellas que los prelados reclamaban en la actualidad respecto del capítulo y de las parroquias (IV).

ii) Visita episcopal de la diócesis: de acuerdo al concilio tridentino ${ }^{36}$ los obispos estaban obligados a visitar sus diócesis por lo menos en el lapso de dos años, período que, según los metropolitanos, hacía sumamente difícil, «por no decir imposible», cumplir el referido precepto en el Reino de España, tanto en razón de las numerosas iglesias que se situaban en cada una de las diócesis, como en razón de la escasez de los medios económicos con los que el visitador delegado podía ser remunerado en vistas a realizar por completo esta obligación; en atención a tales dificultades, entendían que era "necesario y razonable», al menos a favor de un número significativo de diócesis, prescribir que en el futuro se llevare a cabo cada cinco años, lo que estaba en conformidad con los lineamientos propuestos por el Concilio Vaticano I respecto de esta situación (V).

iii) Concilio provincial y sínodo diocesano: sería de gran utilidad, sugerían los prelados, que se fijare por anticipado el concilio provincial, que habría de celebrarse alrededor del sexto año, porque, según los prelados, parecía que una celebración más frecuente se hacía innecesaria, dado que se mantenía la fluidez de comunicación personal, la que todas las iglesias podían tener con el romano pontífice y con las congregaciones de la curia romana; además, esta propuesta no se apartaba mucho de los lineamientos propuestos por el Concilio Vaticano I respecto de esta situación (VII).

En cuanto al sínodo diocesano, también sugerían ampliar los tiempos de su celebración de un año, tal como estaba establecido en el Concilio de Trento, ${ }^{37}$ a tres años, lo que igualmente estaba de acuerdo con los lineamientos del Concilio Vaticano (VI).

iv) Vicario capitular: a partir de la experiencia de las divisiones y escándalos que frecuentemente tenían lugar en torno a la observancia de los preceptos tridentinos ${ }^{38}$ acerca de la elección del vicario capitular en sede vacante, sugerían los metropolitanos que debía preferirse decidir que, una vez muerto el Ordinario, por el mismo derecho adquiriere jurisdicción su vicario general o el que, de cualquier modo, nombrare el metropolitano, el obispo más antiguo o el mismo nuncio apostólico, a fin de que alguien fuere designado administrador diocesano hasta que la Iglesia viuda fuere provista canónicamente de un nuevo pastor (VIII).

En cuanto a las facultades del vicario capitular, se proponía desde España que no pudiere, en el plazo de tres años, convocar un sínodo diocesano, ni llamar a concurso para la cura de almas, ni pudiere conferir con colación libre beneficios inmuebles, ni modificar el régimen del seminario excepto por causa grave y con conocimiento del metropolitano, $y$, si se tratare del seminario metropolitano, con conocimiento del obispo más antiguo (IX).

v) Canónigos: cualquier modificación de aquellos aspectos que concernieren a la residencia de los canónigos y a su asistencia, debía ser justificada no solo en derecho, sino que también de modo razonable. Para que prestaren su servicio diario a la Iglesia, entendían los prelados que no era

${ }^{36}$ Concilium Tridentinum (en adelante Conc. Trid.) sess. 24 c. 3 de ref.

37 Conc. Trid. sess. 24 c. 2 de ref.

38 Conc. Trid. sess. 24 c. 16 de ref. suficiente, a modo de incentivo, separar la tercera parte de los frutos del beneficio y distribuirla entre los asistentes al coro, sino que era necesario, para evitar completamente los fraudes, establecer repartos de todos los frutos de manera que únicamente los canónigos presentes en el coro pudieren beneficiarse de ellos. En cuanto el privilegio de tres meses de ausencia concedido por el Tridentino, este debía conservarse, pero no debía reconocerse ninguna otra causa legítima que eximiere del coro, excepto la enfermedad del beneficiado, cuando ésta hubiere sido comprobada por el testimonio de dos canónigos quienes, como visitantes del enfermo y habiendo oído al médico, debían estar obligados en conciencia a decir si acaso el enfermo podía o no ir a la iglesia (X).

vi) Beneficios parroquiales: según los arzobispos, había suma necesidad de que los beneficios parroquiales estuvieren adscritos a la libre disposición del obispo o, al menos, si existieren inmuebles, se entregaren a los obispos mayores facultades de las que disponían para que, existiendo causas justas, pudieren trasladar al párroco propio, incluso contra su voluntad, a otro beneficio y asimismo privarlo de su propia parroquia (XI).

\section{LIBRO II: IUDICIUM}

\section{Propuesta general}

Las propuestas referidas al proceso son las más numerosas y se inician con una proposición general, que apuntaba a una regulación más orgánica de la materia procesal. Al respecto, entendían los prelados hispanos que era muy deseable una ley procesal que, respondiendo a la organización de los tribunales eclesiásticos, pudiere contener de modo técnico y completo: 10 prescripciones comunes a todo procedimiento; 2 ㅇ las propias de la jurisdicción voluntaria; 3 ㅇ las propias de la jurisdicción contenciosa tanto en lo civil como en lo criminal; 4 o las propias de la jurisdicción contenciosoadministrativa si, eventualmente, con moderación, se considere que debía ser introducida en el derecho de la Iglesia; 50 las especiales para los procesos penales extraordinarios, esto es económicas, respecto de la suspensión ex informata, y de las censuras en general. Por eso, estaba también en su voto, que se hiciere obligatoria la institución de un instructor distinto del juez, de lo que trataba la instrucción de la Sagrada Congregación de Obispos y Regulares del 11 de junio de $1880,{ }^{39}$ algunas de cuyas prescripciones debían ser clarificadas y complementadas (XII).

\section{Reglas comunes a todo procedimiento}

i) Propuestas de conjunto: en general, y abordando diversas materias en particular, se proponía desde España que, en todo caso, debía favorecerse la comparecencia personal, debían restringirse las inhabilidades, la justicia debía administrarse con el menor gasto posible y los litigantes temerarios debían ser reprimidos con más eficacia (XIII). También había que empeñarse en que desaparecieren ciertas prescripciones que olían a arcaísmos, como, por ejemplo, aquella que prohibía que las mujeres pudieren ser 
llevadas ante el juez contra su voluntad, y otras muchas que concernían a ciertos juramentos, días festivos, mercados, peregrinaciones a Roma, etc., etc. (XIV).

ii) Fuero competente: la regla «actor sequitur forum rei» según la cual el actor sigue el fuero del demandado, necesitaba explicarse de la siguiente manera que proponían los arzobispos: si el demandado hubiere cambiado fraudulenta o dolosamente su domicilio, se le pudiere demandar, a voluntad, en el último domicilio legal o dondequiera que se encontrare (XV). Complementaba esta propuesta otra referida al domicilio y cuasidomicilio, pues, habida consideración de la movilidad de las personas que se desplazaban de un lado a otro, debían ser clarificados con mayor precisión los requisitos de uno y otro, principalmente en cuanto a su adquisición y pérdida (XVI).

Hicieron también una propuesta en orden a la prórroga de jurisdicción, si bien reconocían los metropolitanos que rara vez tenía lugar el modo de elegir el fuero mediante prórroga de jurisdicción, pero, puesto que este modo se juzgaba digno de ser conservado como muestra del aprecio de la Iglesia por respetar las instituciones verdaderamente libres, había que aspirar a que, mirada atentamente la organización de los tribunales, se indicaren con acuciosidad los negocios y casos en los que se pudiere aplicar (XVIII).

iii) Medios de prueba: tomando nuevamente en cuenta la movilidad de las personas y para facilitar la prueba de la condición civil de soltería y del estado de vida anterior en cuanto a contraer matrimonio y a recibir las órdenes sagradas, proponían los prelados que había que considerar la información de testigos o la garantía de un varón probo con juramento supletorio (XVII).

iv) Continencia de la causa: si bien la continencia de la causa no debía ser dividida, era necesario explicar cuándo la continencia se entienda podía ser dividida, y también completar los preceptos mediante los cuales fueren reguladas la conexión de causas y de acciones, y también la acumulación de actores (XIX).

v) Cuestiones prejudiciales: consideraban los prelados hispanos que negocio «verdaderamente de la máxima importancia» era el tratamiento de aquellas cuestiones que se escuchaban previamente y de aquellas que se llamaban prejudiciales, por lo que consideraban «sumamente deseable» que el conjunto de ambas se explicare por medio de reglas adecuadas para su deducción, tramitación y resolución. Si se trataba de competencia jurisdiccional, debía establecerse, claramente, que se extinguía y terminaba por decreto único del superior (XX).

vi) Plazos: «para evitar los peligros de un arbitrio inmoderado y para proteger la uniformidad» era la razón por la que los arzobispos hispanos consideraban «deseable» que fuere establecido y delimitado lo que concernía a los días hábiles e inhábiles, los plazos judiciales, la duración de estos - cuya duración convenía que fuere breve-, su prorrogabilidad o improrrogabilidad, su condición ordinaria o extraordinaria y el modo de calcularlos, las consecuencias de la contumacia y las facultades del juez en función de su oficio ya fuere ad honorem o a sueldo (XXI).

vii) Recusación de los jueces: en lo referente a las recusaciones de los jueces, había que definir los casos en los cuales los jueces debieren ser considerados inhábiles; esto a condición de que no fuere necesario recurrir a árbitros.
El juez mismo debería pronunciarse acerca de la existencia o inexistencia de la inhabilidad. Si se declarare hábil, y los litigantes, o alguno de ellos, fuere de opinión contraria, la cuestión debía tratarse de modo breve, como un incidente, y debía ser concluida por un único decreto superior; si el juez inferior se hubiere inhibido, estaría obligado a explicar cuanto antes su inhibición al superior para que aprobare la misma, si la encontrare justa, o, de otro modo, la revocare y corrigiere disciplinariamente al juez inferior (XXII).

viii) Conciliación: el acto de conciliación «tiene que ser muy bien regulado, como institución obligatoria general», de manera que sin él la comunicación escrita de la querella (libelli oblatio) no pudiere tener lugar. Asimismo, debían definirse los casos en los cuales razones de bien público $u$ otras especiales impidieren intentar una conciliación. Ahora bien, el acto debía celebrarse ante un juez, de allí que estando presentes los defensores, llamados en España «hombres buenos», el juez tuviere la potestad de pronunciarse justa y equitativamente, por ejemplo, de la separación semestral en las causas de divorcio, etc., sobre todo cuando la discordia tiene como fundamento un movimiento repentino de ira, u otra causa leve o de breve duración. Agregaban los prelados que a través de esta vía se habían evitado «innumerables divorcios en algunas diócesis de España», donde la práctica anteriormente mencionada se había arraigado, la cual ayudaba admirablemente a la conciliación de las voluntades (XXIII).

ix) Recursos: aunque el derecho canónico, «fundado en el derecho de Justiniano", prohibía una tercera apelación, ocurría, según explicaban los metropolitanos que, una vez propuesta la segunda apelación a favor de una y otra parte, se seguía que el asunto se prolongaba hasta una quinta instancia, por lo que era necesario enfrentar este mal estatuyendo que los negocios canónico-civiles terminaren de modo general mediante doble sentencia conforme, sin perjuicio de la potestad de las partes de acudir al tribunal superior en casación tal como ocurría en el derecho «cesáreo» (XXIV).

Además, había que procurar que, por sobre todo, se observare lo que el Concilio de Trento $^{40}$ había decretado "con suma sabiduría», en el sentido de que no estuviere permitido apelar sino de una sentencia definitiva o interlocutoria que tuviere fuerza de definitiva (XXVI). En todo caso debían proscribirse totalmente los recursos fútiles y engañosos, así como también las apelaciones de tal especie (XXVII) y debía introducirse y regularse el recurso ordinario de queja, a favor de los casos en los cuales fuere denegada la apelación y en casos similares (XXVIII).

Finalmente, en materia de recursos, los prelados sugerían que podía conservarse el precepto del Concilio de Trento $^{41}$ acerca de seleccionar el testimonio de los actores que debía ser remitido al tribunal superior en las apelaciones con efecto devolutivo. Ahora bien, en lo tocante a las apelaciones con efecto suspensivo las mismas actas originales debían ser enviadas al superior, lo que no solo respondería mejor a los efectos de la apelación, sino también llegaría a ser más económico (XXIX).

\footnotetext{
40 Conc. Trid. sess. 13 c. 1 de ref; sess. 24 c. 20 de ref.

41 Conc. Trid. sess. 24 c. 20 de ref.
} 
x) Juicios criminales: consideraban los arzobispos que debía tenerse cuidado de que los juicios criminales fueren más rápidos, especialmente para remover los párrocos indignos, para cuya celeridad podían consultarse con provecho las explicaciones del Tridentino, ${ }^{42}$ y además, por las misma razones de celeridad, las que se proponían en la instrucción de la S. C. de Obispos y Regulares de $1880,{ }^{43}$ las cuales, como ya lo habían advertido en uno de los postulata anteriores (XII), sería necesario explicar y completar con mayor precisión, señalando también un número menor de instancias por medio de las cuales debieren resolverse en el futuro los procesos criminales (XXV).

xi) Fuero de los clérigos: se quejaban los arzobispos de que "las sapientísimas normas de nuestro derecho» referidas al fuero de los clérigos, "nunca se observan» y no era raro que un clérigo tuviese que comparecer ante un juez laico, por lo que sugerían que, en situaciones similares, pudieren ser prescritas las siguientes o similares normas: 1 ㅇque un clérigo llamado como testigo debiere comparecer ante el Ordinario a pedir licencia; 20 que lo mismo debiere hacer el clérigo citado ante un juez laico, pero que en este caso se extendiere al Ordinario el libelo o causa por la cual fuere citado; 3오 si por cualquier razón no pudiere acudir al Ordinario por licencia, que comparezca, sin embargo, ante el juez y ante el mismo declare y jure cuanto fuere necesario, emitiendo protesta de no renunciar al fuero y otros derechos, poniéndolo en conocimiento del Ordinario tan pronto como fuere posible; 4ㅇ que el clérigo no necesitare licencia del Ordinario para poder reconvenir ante un juez laico a una persona igualmente laica que antes lo hubiere citado ante el mismo juez (XXX).

\section{LIBRO III: CLERUS}

\section{Vida y honestidad}

«Sería sumamente necesario estimular y fomentar la vida en común de los clérigos seculares»; era la primera de este grupo de propuestas, para obtener lo cual sugerían que se les concediere ayuda y consideración para que se ejercitaren en ella (XXXI). Con palabras similares - "será muy conveniente»- proponían seguidamente que se otorgaren las máximas facilidades para la creación de alguna congregación de varones con votos simples, que se asignare al servicio de los sacerdotes (XXXII). Y para los clérigos enfermos y de edad avanzada pedían esfuerzo - «hay que esforzarse»- para que se crearen asociaciones de auxilio mutuo, por ejemplo, montes de piedad, en las diócesis en las que no hubiese establecido nada similar, para que hubiere una subsistencia segura para ellos (XXXIV).

Una propuesta especial fue dedicada a la cohabitación con mujeres, la que debía quedar «absolutamente prohibida», excepto con las madres, hermanas, sobrinas en primer grado y el auxilio de otras sin hijos, o con tías maternas de edad avanzada (XXXIII). Y en cuanto a las tareas que podían desempeñar, sugirieron que los clérigos fueren libres para trabajar en las artes y oficios mecánicos, siempre que el decoro sacerdotal y las sagradas obligaciones del ministerio no fueren menoscabadas por lo que, en consecuencia,

\footnotetext{
42 Conc. Trid. sess. 21 c. 6 de ref.

43 Véase nota 39.
}

solicitaban que se les otorgare facultad para que pudieren vender, sin establecimiento comercial, objetos elaborados por mano propia y, al mismo tiempo, comprar las materias primas necesarias para desarrollar su propio trabajo (XLII).

\section{Bienes temporales}

Hubo también algunas propuestas en materia patrimonial: dados la escasez de los beneficios y la pobreza de aquellos que se consagraban a los estudios eclesiásticos, entendía que "sería muy conveniente» que el título de servicio a la Iglesia fuere lo ordinario y suficiente (XXXV), debiendo suprimirse el título de ordenación que se denominaba de patrimonio puesto que, al menos en España, se encontraban muy pocos que podían constituir un verdadero patrimonio, y casi todos no eran títulos reales como tal. Por otra parte, las sociedades o asociaciones a cuya creación se referían en un postulatum anterior (XXXII), atenderían a los sacerdotes para que su sustento estuviere siempre seguro (XXXVI).

En materia de enajenación de bienes temporales, entendían los prelados que convenía que el Ordinario, sin perjuicio de la necesidad de impetrar el beneplácito apostólico, pudiere autorizar la enajenación de los bienes de la Iglesia, al menos hasta diez mil libelos, de acuerdo al valor que entonces tenía la moneda y del desarrollo de la vida económica (XXXVII). Y en cuanto al beneplácito apostólico, consideraban sumamente oportuno que en la enajenación que hicieren algunas iglesias, asociaciones o entidades eclesiásticas a otras también eclesiásticas, al interior de la misma diócesis, no se requiriere el beneplácito apostólico (XXXVIII).

En lo referido a testamentos y contratos, pedían que se exigiere que cualquier cambio se hiciere ante la vista de todos; y «convendría muchísimo» que la doctrina acerca del mutuo y de los intereses fuere expuesta más clara y precisamente (XXXIX). Una propuestas especial hacían para los testamentos de religiosos, sugiriendo que se extendiere a la Iglesia universal lo que había sido dispuesto a favor de Italia en una instrucción de la Sagrada Penitenciaría de 18 de abril de 1867,44 mediante la cual se disponía que era suficiente la autorización del Ordinario para que una religiosa pudiere redactar testamento, y un permiso del superior general si se trataba de un religioso; incluso más, entendían los prelados que "sería sumamente conveniente» que fuere declarado que las autorizaciones antes mencionadas también fueren suficientes para cualquier acto de dominio o de propiedad (XL).

Una propuesta especial estuvo referida a los cementerios, respecto de los cuales los prelados pedían que fueren determinados "con suma claridad» los derechos de la Iglesia en cuanto a los cementerios, a causa de las continuas invasiones del poder civil; y debían precisarse cuándo y de qué manera podrían ser privados de sepultura eclesiástica quienes no cumplieren el precepto pascual, los usureros, concubinarios, carbonarios, libre pensadores, etc. (XLI).

Brevemente se refirieron al derecho de patronato, para sugerir que los derechos útiles y honoríficos de los patronos, fundadores, etc. de las iglesias o de cualquier tipo de beneficios se limitaren a una sola generación o a la segunda (XLII).

\footnotetext{
44 En Acta Sanctae Sedis 3, 1867, 151-156.
} 


\section{LIBRO IV: CONNUBIA ${ }^{45}$}

\section{Esponsales}

Era preciso, según la propuesta hispana, dejar establecido que los esponsales no tuvieren ningún valor, a no ser que hubieren sido investidos con todas las solemnidades como ocurría en España; pero, incluso, investidos con ellas, debían perder su valor si no se renovaren anualmente; $y$, además, el impedimento de pública honestidad originado de los esponsales debía eliminarse (XLIV). Esta sugerencia sobre el impedimento de pública honestidad ponía en relación este postulatum con el siguiente referido a los impedimentos.

\section{Impedimentos}

"Sería sumamente conveniente», escribían, que de acuerdo a lo que había sido requerido en el Concilio Vaticano, se suprimieren algunos impedimentos dirimentes que enunciaban así: i) el impedimento de consanguinidad de cuarto grado y también de tercero, o, como mínimo, de tercero con cuarto; ii) el impedimento de parentesco espiritual, con excepción del que se originare entre el padrino y el bautizado; iii) el impedimento de segundo grado de afinidad por cópula ilícita; iv) el de tercero y cuarto grado de afinidad por cópula lícita; v) el de segundo grado de pública honestidad por matrimonio válido; vi) el impedimento de crimen cuando existiere solo adulterio sin maquinación: vii) el impedimento de parentesco legal (XLV).

Para la reducción de dichos impedimentos, expresaban los prelados que, entre otras circunstancias, era preciso tener a la vista el enfriamiento de la fe «en el tiempo actual», la mala disposición de los abogados para la aplicación de la ley y, simultáneamente, las frecuentes proposiciones de personas maliciosas al matrimonio civil o al concubinato (XLIX).

Respecto de los impedimentos que se mantuvieren, proponían que no concedieren dispensas; supuesta esa posibilidad, que se aumentaren las facultades de los Ordinarios para que, en parte o también en su totalidad, no cobraren las tasas cuando así lo hubieren juzgado resolver «en el Señor». Y los ingresos que "en la actualidad» se percibían en razón de las dispensas podían ser compensados asignando el sumo pontífice cierta participación en las distribuciones corales y parroquiales de la Iglesia universal, o por imposición de una pensión muy módica en los beneficios de cualquier clase que existieren (XLVI).

\section{Matrimonios por sorpresa}

Constaban los prelados que "por causa del defecto de fe en el pueblo cristiano, la corrupción de las costumbres y la excesiva permisividad en estos tiempos calamitosos", muchos fieles que padecían de una gran ignorancia religiosa, "astutamente y contra lo que saben», lo que había sido desconocido por "los antiguos en su inocencia», habían abierto sus ojos al mal, de donde habían aparecido «muchos

45 Un primer análisis de las propuestas españolas referidas al matrimonio, en comparación con las sugeridas por la provincia eclesiástica de Chile, en Salinas 2018. matrimonios infelices denominados por sorpresa», ${ }^{46}$ los que no eran queridos por el proprio párroco o el Ordinario, "antes bien contraídos de forma repugnante». Para precaver tales y tantos males y escándalos perturbadores del orden, postulaban los arzobispos que los matrimonios celebrados bajo tales circunstancias debían ser declarados nulos (XLVII).

\section{Divorcio}

Convenía determinar taxativamente el número y la índole de las causas que podrían dar lugar al divorcio, tanto temporal como perpetuo; y puesto que frecuentemente ocurría que el divorcio semipleno perpetuo se pedía a causa del adulterio, que no se probaba con posterioridad, aunque resultare que el acusado había procedido con menor rectitud, sugerían que se estableciere que la inmoralidad manifiesta fuere causa suficiente para determinar el divorcio temporal (XLVIII).

\section{LIBRO V: CRIMEN}

\section{Propuestas generales}

La primera de las propuestas en materia de delitos y penas era una propuesta general, en la que manifestaban la conveniencia de reducir a un único texto lo que se refería a las penas, los delitos y las irregularidades. Para formular este postulatum, tenían a la vista lo que ya se había hecho a propósito de las censuras por la bula Apostolicae Sedis ${ }^{47}$ y, a propósito de los libros y escritos, por la constitución Officiorum et munerum (L). ${ }^{48}$ Esta sugerencia era complementada, en el mismo sentido, por otra que pedía reunir en una sección especial todo aquello que, concerniendo a los delitos y las penas de los regulares, se encontraba esparcido en distintos lugares del Corpus luris (LII).

En el mismo sentido de mayor claridad, se sugería que se enumeraren taxativamente y con mucha precisión, «en un orden que no ofrezca dudas», los casos en los que un ministro cometiere delito, de manera que se eliminaren completamente "las contradicciones no infrecuentes entre las rúbricas y sus textos dependientes en el libro $\mathrm{V}$ de las Decretales» (LVI).

De carácter más conceptual era la propuesta de que se requerían "muy especialmente» conceptos precisos respecto de la naturaleza del delito, las condiciones respecto del mismo, la capacidad del delincuente y «otras cosas de este género» (LI).

\section{Guerra justa-guerra injusta: defectu lenitatis}

Puesto que era difícil determinar con autoridad cuándo una guerra es justa, cuándo es verdaderamente injusta,

46 En el texto latino la expresión «por sorpresa» está en español y escrita con letras mayúsculas.

47 Pío IX, 1869-1870. «Constitución apostólica Apostolicae Sedis, quae ecclesiasticae censurae latae sententiae limitantur, 12 octubre 1869». Acta Sanctae Sedis 5, 305-331.

48 León XII, 1896-1897. "Constitución apostólica Officiorum munerum de prohibitione et censura librorum, 25 enero 1897». Actae Sanctae Sedis 29, 388-400. 
cuándo un ejército, este u otro, se encuentra a la ofensiva, cuándo a la defensiva; y, por otra parte, existía el servicio militar obligatorio no voluntario, era evidente para los prelados que, para suprimir las angustias que eso causa, había que prescindir de tal distinción o bien había que suprimir, en este caso, la irregularidad ex defectu lenitatis (LIII).

\section{Arbitrio judicial}

Fue una propuesta breve, las más breve de todas: el arbitrio judicial en materia penal debía restringirse «más y más» (LIV).

\section{Penas}

En lo que se refiere a la aplicación de las penas, entendía los prelados españoles que «no sería inoportuno en el nuevo Código» exponer más claramente cuándo realmente las penas fueren impuestas por el derecho y señalar los casos en los que fuere necesaria una sentencia declaratoria del juez para la ejecución de ellas (LV).

\section{AVANCE PARA UNA PRIMERA VALORACIÓN DE ESTAS PROPUESTAS}

Expuestos brevemente los 56 postulata que enviaron los metropolitanos españoles a Roma en respuesta a la invitación hecha por la Santa Sede al inicio de la codificación de los cánones para que sugirieran las principales reformas que debían introducirse al derecho canónico vigente, avanzo seguidamente unas primeras consideraciones para hacer una valoración de conjunto de los mismos.

\section{Fuentes utilizadas}

Hay una fuente canónica que está permanentemente presente en el informe: las Decretales de Gregorio IX, pues, como lo he señalado, la ordenación que se da a las diferentes propuestas está definida por la estructura de ese cuerpo canónico. En efecto, referidas al primero de los cinco libros de las Decretales, comúnmente denominado ludex, que trata de algunas fuentes del derecho, de los jueces eclesiásticos y, en general, de los prelados, son las primeras 11 proposiciones; siguen las 18 propuestas acerca de los juicios y procesos, coincidiendo con el libro segundo de las Decretales que trata de los juicios civiles y su sustanciación -ludicium-; siguen 13 postulata dedicados a los clérigos, en consonancia con el libro tercero de las Decretales que trata de la disciplina de los clérigos y de las cosas eclesiásticas, conocido como Clerus; continúan las 6 sugerencias referidas al matrimonio, del que trata el libro cuarto de las Decretales -Connubia-; y terminan los siete postulata sobre delitos y penas, materia regulada en el libro quinto de las Decretales - Crimen-.

Sin perjuicio de lo anterior, las propuestas hispanas se limitan a exponer con brevedad las reformas que postulan, sin hacer mayor referencia a las fuentes que las inspiran. Hay ocasiones, sin embargo, en que algunas fuentes canónicas son mencionadas expresamente, siendo el Concilio de Trento la más citada, con seis referencias. Las referencias al concilio, sin embargo, se hacen con diversas finalidades. Las hay para instar a que se aplique, como ocurre cuando proponen que no esté permitido apelar sino de una sentencia definitiva o interlocutoria que tenga fuerza de definitiva, lo que había sido decretado por el concilio «con suma sabiduría» (XXVI); o para que el concilio se conserve, lo que ocurre cuando los prelados se refieren a la práctica de seleccionar el testimonio de los actores que ha de ser remitido al tribunal superior en las apelaciones con efecto devolutivo, precepto tridentino que "puede conservarse» (XXIX). También se sugiere conservar, pero añadiendo alguna precisión, el privilegio concedido por el tridentino a los canónigos de ausentarse por tres meses del coro, pero sin reconocerse «ninguna otra causa legítima que exima del coro», con excepción de la enfermedad del beneficiado debidamente acreditada.

En cambio, se pide reformarlo en cuanto a las oportunidades en las que la diócesis había de ser visitada por el prelado - que debía hacerse una vez cada dos añossugiriéndose cambiarlo por una vez cada cinco años, lapso que sería en su opinión "necesario y razonable» (V). Una reforma similar se pide para la celebración del sínodo diocesano, el que podría celebrarse en el lapso de tres años (VI). También los metropolitanos sugieren una reforma a partir de la experiencia poco feliz de la aplicación de las normas tridentinas en cuanto a la elección del vicario capitular en sede vacante, las que frecuentemente daban lugar a «divisiones y escándalos», por lo que proponían que, una vez muerto el Ordinario, por el mismo derecho adquiriere jurisdicción su vicario general o aquél que fuere nombrado por el metropolitano, por el obispo más antiguo o por el nuncio, hasta que la "Iglesia viuda» fuere provista de un nuevo pastor (VIII). Finalmente, las normas del concilio se proponen como modelo a consultar para que se dicten normas que aceleren la tramitación de los juicios criminales, especialmente para remover a los párrocos indignos (XXV).

El Concilio de Trento no es el único concilio invocado, pues también hay referencias al Concilio Vaticano I, el que es citado en cuatro oportunidades para servir de fuente de inspiración para las reformas que se proponen, las que ya habían sido sugeridas con ocasión de esa asamblea: ampliar a cinco años la frecuencia de la visita episcopal a la diócesis (V), y a tres años el plazo para la celebración del sínodo diocesano (VI); la celebración cada seis años de los concilios provinciales, «lo que no se aparta mucho de los lineamientos propuestos por el Vaticano respecto de esta situación» (VII); y las supresiones de algunos impedimentos matrimoniales "lo que ya ha sido requerido en el Concilio Vaticano» (XLV).

Además de las referencias conciliares, se citan, individualizadamente, algunas normas emanadas de congregaciones romanas. Así, en dos ocasiones se cita la instrucción de la Sagrada Congregación de Obispos y Regulares de 11 de junio de $1880^{49}$ sobre ajustes al procedimiento económico en las causas disciplinares y criminales de los clérigos: la primera, para que se hiciere obligatoria la institución de un instructor distinto del juez, de lo que trataba dicha instrucción (XII), y la segunda para utilizar sus normas a efectos de producir una mayor celeridad en los procesos criminales (XXV); ambas citas tienen, sin embargo, un elemento común, pues en los dos lugares, si bien se aconseja el uso de dichas normas, se insta a que las mismas debían

\footnotetext{
49 Acta Sanctae Sedis 13, 1880, 324-336.
} 
ser clarificadas y complementadas. Se cita también la instrucción de la Sagrada Penitenciaría de 18 de abril de 1867 $(\mathrm{XL})$, para sugerir que se extendiere a la Iglesia universal lo que había sido dispuesto a favor de Italia, ${ }^{50}$ en el sentido de que era suficiente la autorización del Ordinario para que una religiosa pudiere redactar testamento, y un permiso del superior general si se trataba de un religioso. Se citan igualmente, las constituciones apostólicas "Apostolicae Sedis» de Pío IX, de 12 de octubre de 1869,51 que limitaba las censuras latae sententiae, y "Officiorum ac munerum», de León XIII, de 25 de enero de 1897,,52 sobre la prohibición y censura de libros, citas que son hechas para proponer la conveniencia de reducir a un texto único lo que se refería a las penas, los delitos y las irregularidades (L).

Pero los metropolitanos españoles no solo utilizaron fuentes canónicas para hacer sus propuestas, sino que también el derecho del Estado español, si bien, en este caso, no lo citan expresamente aunque, al parecer, hacen uso de él. Es lo que sucede cuando sugieren a Roma la introducción y regulación del recurso ordinario de queja, a favor de los casos en los cuales fuera denegada la apelación y en casos similares (XXVIII). El recurso de queja, tal cual estaba regulado en la Ley de Enjuiciamiento Civil (art. 398), procedía cuando, habiéndose introducido el recurso de apelación contra autos o providencia dictadas por los jueces de tribunales de primera instancia, se hubiese denegado su admisión, en cuyo caso podía el afectado interponer recurso de queja ante la audiencia que correspondiese. A la luz de esta norma estatal, no es aventurado pensar que es ella la que tenían en mente los prelados españoles cuando pedían que se introdujere y regulare el recurso ordinario de queja en la situación señalada. No en vano, algunos de los metropolitanos que suscribieron este informe tenían estudios y grados en derecho del Estado.

\section{Ideas codificadoras}

Las dos constituciones apostólicas recién citadas resultan particularmente interesantes por la razón por la que eran invocadas: ambas constituciones habían sido intentos de sistematizar - a la manera de los modernos códigos legislativos estatales - las materias de que se ocupaban cada una - censuras latae sententia y prohibición y censura de libros-; es decir, se trataba, si se quiere, de pequeños códigos referidos a esas específicas materias, que venían a adelantar el proyecto mayor de reducir a un solo texto el derecho canónico, que era, precisamente, el proyecto en que la Iglesia se encontraba empeñada. Se trataba, así, de una cita del todo pertinente que, además, tenía el mérito de mostrar la perfecta consonancia que en esta materia tenían los prelados hispanos con los codificadores romanos. Esta misma idea codificadora es posible advertirla en la primera de las propuestas que formularon en materia procesal (XII), en la que planteaban que era «muy deseable» una ley procesal que, respondiendo a la organización de los tribunales eclesiásticos, pudiere contener de modo técnico y completo las prescripciones comunes a todo procedimiento y

\footnotetext{
50 Acta Sanctae Sedis 3, 1867, 151-156.

51 Véase antes nota 47.

52 Véase antes nota 48.
}

las propias de las distintas jurisdicciones que señalé en su momento, páginas arriba. Y lo mismo es posible advertir en otra propuesta española, como la que pedía reunir en una sección especial todo aquello que, concerniendo a los delitos y las penas de los regulares, se encontraba esparcido en distintos lugares del Corpus luris (LII).

La codificación iusracionalista que se había desarrollado en los derechos de los Estados y que ahora quería asumir la Iglesia, se caracterizaba por la precisión del lenguaje, pues, a diferencia de lo que sucedía en el ius commune al que vino a sustituir, se trataba de redactar normas breves, precisas y apodícticas. Esta característica de la codificación como técnica fijadora del derecho se encuentra también en las propuestas hispanas, como cuando hacían presente que se requería "muy especialmente» conceptos precisos respecto de la naturaleza del delito, las condiciones respecto del mismo, la capacidad del delincuente y "otras cosas de este género» (LI).

Los modernos códigos eran textos unitarios y unívocos, en los que se trataban de superar las frecuentes contradicciones que se encontraban en el derecho que vinieron a sustituir, en el que, con frecuencia, se encontraba el defecto propio de los derechos de juristas, como era el derecho común: las diferencias y aún contradicciones de las diversas opiniones de la doctrina y la legislación. Este defecto no era ajeno al derecho canónico vigente y ya había sido puesto de relieve en el Concilio Vaticano I, cuando, por ejemplo, el postulatum de once obispos franceses ${ }^{53}$ al que hecho referencia al iniciar estas páginas, hacían presente que el estudio del derecho canónico estaba lleno de dificultades inextricables y "casi infinitas», por lo que el más vasto campo está abierto a las controversias y procesos, y las conciencias estaban oprimidas por miles de angustias «y empujadas al menosprecio de la ley». ${ }^{54}$ Esta idea se encuentra detrás del planteamiento hispano que pedía que se enumeraren taxativamente y con mucha precisión, "en un orden que no ofrezca dudas», los casos en los que un ministro cometiere delito, de manera que se eliminaren completamente "las contradicciones no infrecuentes entre las rúbricas y sus textos dependientes en el libro V de las Decretales» (LVI).

\section{Realidades locales de la Iglesia española}

A través de algunas propuestas españolas es posible ver algunas realidades locales que presentaba la Iglesia española en los primeros años del siglo XX. Ello es posible advertirlos desde el primero de los postulata que formulan, cuando piden que, para que la ley o precepto fuere promulgado debidamente y constare su legitimidad, debían divulgarse, "como es uso en nuestras curias diocesanas españolas, la hoja o periódico oficial por medio del cual se haga evidente tal obligación» (I). El uso del acto de conciliación practicado en los procesos canónicos es otra realidad local española

53 Mansi 1927: col. 341-342.

54 Otras quejas similares se encuentran en los postulata suscritos por 37 obispos napolitanos, ibíd., col. 378-456, esp. 449-450; 15 obispos alemanes, ibíd., col. 352-378, esp. 355; el episcopado belga, ibíd., col. 456-461, esp. 460-461; 33 padres de diversas naciones, ibíd., col. 478-479; los obispos de las provincias eclesiásticas de Quebec y Halifax, ibíd., col. 467; y un grupo de prelados de Italia central, ibíd., col. 552-553. 
que aparece reflejada cuando postulan que el acto de conciliación sea regulado como institución obligatoria general, pues, "a través de esta vía se han evitado innumerables divorcios en algunas diócesis de España, donde la práctica anteriormente mencionada se ha arraigado, la cual ayuda admirablemente a la conciliación de las voluntades» (XXIII).

Un nuevo «localismo» es posible advertir en materia de esponsales cuando planteaban que era preciso dejar establecido que los esponsales no tuvieren ningún valor, a no ser que hubieren sido investidos con todas las solemnidades como ocurría en España (XLIV). Aun cuando se exigía que los esponsales se manifestasen con palabras $u$ otros signos equivalentes, no había prescrita canónicamente ninguna formalidad especial. En el derecho español, sin embargo, una pragmática de Carlos III de 28 de abril de 1803,55 había dispuesto que «en ningún tribunal eclesiástico ni secular de mis dominios se admitirán demandas de esponsales, sino es que sean celebrados por personas habilitadas para contraer por sí mismas según los expresados requisitos y practicados por escritura pública», caso en el que se procedería como si fueran asuntos puramente civiles. Esta exigencia legal había sido reconocida por la S. Congregación del Concilio el 31 de enero de $1880^{56}$ la que, respondiendo una duda sobre un caso de Plasencia, ${ }^{57}$ había declarado que "los esponsales celebrados en España sin escritura pública, deben ser considerados nulos», la que podía extenderse ante notario público civil o eclesiástico y ante testigos.

\section{Problemas de la Iglesia española}

Pero no solo es posible advertir algunas prácticas de la iglesia local en los postulata de los metropolitanos españoles, sino que también algunos problemas que las aquejaban, los que eran motivo para sugerir reformas al derecho canónico vigente que les ayudarían a resolverlos. El primero de ellos emerge cuando pedían que se ampliare el plazo para la visita episcopal de la diócesis a cinco años en lugar de los dos establecidos por el Concilio de Trento, puesto que se hacía «sumamente difícil, por no decir imposible», cumplir el referido precepto en el Reino de España, tanto en razón de las numerosas iglesias que se situaban en cada una de las diócesis, como en razón de la escasez de los medios económicos con los que el visitador delegado podía ser remunerado en vistas a realizar por completo esta obligación. Según los prelados, el nuevo plazo sugerido "será necesario y razonable, al menos a favor de un número significativo de diócesis» (V).

Un problema no menor es el que deja traslucir la petición de que se dispusiera que una vez muerto el Ordinario, por el mismo derecho, adquiriere jurisdicción su vicario general o el que, de cualquier modo, nombraren el metropolitano, el obispo más antiguo o el mismo nuncio apostólico, a fin de que alguien fuere designado administrador diocesano hasta que la Iglesia viuda fuere provista canónicamente de un nuevo pastor; la razón que daban eran «las divisiones y escándalos que frecuentemente tienen lugar en torno a la observancia de los preceptos tridentinos ${ }^{58}$ acerca de la elección del vicario capitular en sede vacante» (VIII).

\footnotetext{
55 Recogida en Novísima Recopilación 10, 2, 18.

56 Acta Sanctae Sedis 13, 1880, 185-192.

57 Manjón 1900, II, 224.

58 Conc. Trid. sess. 24 c. 16 de ref.
}

Otro problema de emerge es el referido a los beneficios parroquiales, para los que pedían libre disposición del obispo o, al menos, si existían inmuebles, se les entregaren mayores facultades que las que tenían el tiempo de la codificación, de manera tal que, existiendo causas justas, pudieren trasladar al párroco propio, incluso contra su voluntad, a otro beneficio $y$, asimismo, privarlo de su propia parroquia (XI). Vinculado a este problema estaba el postulatum en que pedían que los juicios criminales fueren más rápido, "especialmente para remover los párrocos indignos», en el que queda a la luz otra dificultad con la que se enfrentaban los obispos, la que iba de la mano con la petición de que se señalare un número menor de instancias por medio de las cuales debieren resolverse en el futuro los procesos criminales, lo que deja entrever los resquicios utilizados por los procesados para alejar en el tiempo la puesta en práctica de la sanción impuesta (XXV).

Algo similar se entrevé cuando pedían que la regla "actor sequitur forum rei» según la cual el actor sigue el fuero del demandado, necesitaba explicarse de la manera que ellos proponían, esto es: si el demandado hubiere cambiado fraudulenta o dolosamente su domicilio, se le pudiere demandar, a voluntad, en el último domicilio legal o dondequiera que se encontrare (XV). El problema del cambio fraudulento de domicilio o cuasi-domicilio estaba vinculado a la creciente movilidad de las personas, la que traía consigo nuevos problemas, por la dificultad que se producía para la prueba de la condición civil de soltería y del estado de vida anterior en cuanto a contraer matrimonio y a recibir las órdenes sagradas; es por lo que, para facilitar dicha prueba, los prelados sugerían que había que considerar la información de testigos o la garantía de un varón probo con juramento supletorio (XVII).

No era el único problema en sede matrimonial, pues hay una expresa referencia a la corruptela de los matrimonios "por sorpresa». La reflexión medieval de los canonistas del ius commune había afirmado el principio «consensus facit nuptias non concubitus", lo que hace el matrimonio es el consentimiento no el concúbito. Pero, si bien se fijó el principio, nada se dijo acerca de la forma en que dicho consentimiento debía prestarse, lo que dio origen a la corruptela de los matrimonios clandestinos, esto es, el matrimonio celebrado con palabras de presente entre los contrayentes, sin la presencia de testigo alguno: puesto que había habido consentimiento matrimonial, el matrimonio era válido y verdadero sacramento; cosa diversa era la prueba del mismo. Esto originó no pocos abusos a los que se puso fin en el Concilio de Trento, ${ }^{59}$ en el que se estableció una forma especial para emitir el consentimiento matrimonial, forma sin la cual el matrimonio era inválido, y que consistía en la presencia de un testigo cualificado, el párroco de uno o de ambos contrayentes, que recibía el consentimiento conyugal en nombre de la Iglesia, y dos o tres testigos comunes. Esta reforma tridentina puso término a los matrimonios clandestinos, pero dio origen a una nueva corruptela, la de los matrimonios "por sorpresa», a la que se referían los prelados hispanos: porque el concilio tampoco dijo nada en cuanto a la forma como debía actuar el párroco al momento de recibir el consentimiento conyugal, lo que

\footnotetext{
59 Conc. Trid. sess. 24 c. 1 de ref. mat.
} 
trajo una nueva forma de abuso, pues ocasiones hubo en que los contrayentes sorprendían al párroco desprevenido y emitían delante de él y de testigos comunes un consentimiento que, en circunstancias ordinarias, el párroco no habría aceptado recibir. Por algún tiempo se dudó si estos matrimonios eran válidos o no, pues quienes entendían que el párroco era el ministro del sacramento del matrimonio, siguiendo la doctrina de Melchor Cano, negaban validez a los matrimonios contraídos por sorpresa. Sin embargo, las declaraciones de las Sagradas Congregaciones quitaron toda duda acerca de la validez de estos matrimonios, si bien eran ilícitos. ${ }^{60}$ La presencia de este postulatum es expresión de que los matrimonios sorpresa no eran un fenómeno aislado en España al punto de suscitar la preocupación de los metropolitanos. De hecho, hasta la literatura de la época se había hecho eco de ellos, ${ }^{61}$ por lo que la Iglesia debió una vez más arbitrar una solución, la que vino una vez iniciado el proceso codificador, con el decreto Ne temere, de Pío X, de 2 de agosto de 1907, cuya entrada en vigencia se produjo el 19 de abril del año siguiente, ${ }^{62}$ en el que dispuso que, para la válida actuación del sacerdote durante la celebración matrimonial, debía él pedir el consentimiento, no siendo suficiente, para la validez, su sola presencia pasiva. El código canónico, una vez promulgado, recogió esta solución en el canon $1095 .{ }^{63}$

Otros problemas se referían a las relaciones entre la Iglesia y el Estado. Esto es claro en materia de fuero de los clérigos el que, no obstante "las sapientísimas normas de nuestro derecho», nunca se observaban por lo que no era raro que los clérigos tuvieran que comparecer ante un juez laico; parecía claro a los prelados que esta situación no iba a cambiar, por lo que proponen algunas medidas que debían adoptarse, las que quedaron expuestas en el postulatum XXX. Problemas similares ocurrían en materia de cementerios, respecto de los cuales los arzobispos pedían que se determinaren «con suma claridad los derechos de la Iglesia», lo que solicitaban «a causa de las continuas invasiones del poder civil» (XLI).

La falta de recursos económicos queda igualmente en claro cuando pedían que se suprimiere el título de ordenación que se denominaba de patrimonio puesto que, "al menos en España, se encuentran muy pocos que puedan constituir un verdadero patrimonio, y casi todos no son títulos reales como tal» (XXXVII), con lo que ponían en evidencia una práctica que no brillaba, precisamente, por su honestidad. Complementaba este postulatum otro que sugería que "sería muy conveniente» que el título de servicio a la iglesia fuere lo ordinario y suficiente; ¿la razón? «la escasez de los beneficios y la pobreza de aquellos que se consagran a los estudios eclesiásticos» (XXXV). Por eso era necesaria la creación de asociaciones de auxilio mutuo, «por ejemplo, montes de piedad [...] para que haya una subsistencia segura para los clérigos enfermos y de edad avanzada» (XXXIV).

\footnotetext{
60 Gómez; De la Fuente 1880, II, 259.

61 Por ejemplo, la novela Los novios, del italiano Alejandro Manzoni.

62 Acta Sanctae Sedis 40, 1907: 525-530.

63 La misma solución se recoge en el canon 1108 § 2 del Código de Derecho Canónico de 1983, en vigencia.
}

\section{Modalidades de las propuestas}

Una lectura atenta de las 56 propuestas enviadas desde España a Roma muestra que no todas ellas aparecen formuladas de la misma manera, lo que permite hacer algunas diferenciaciones. Por de pronto, hay algunos postulata que se limitan a sugerir, en general, la conveniencia de que se regulen en el nuevo código determinadas materias, sin hacer mayores especificaciones: es lo que sucede, por ejemplo, cuando, en materia procesal, sugieren una ley procesal que, "de modo técnico y completo" pueda contener las prescripciones comunes a todo procedimiento, las propias de las jurisdicciones voluntaria, contenciosas civil, criminal y administrativa y las propias de los procesos penales extraordinarios (XII); o cuando hacen presente que convendría reducir a un único texto lo que se refiere a las penas, los delitos y la irregularidades (L); o cuando, en el mismo sentido, piden que se reúna en una sección especial todo aquello que, concerniendo a los delitos y las penas de los regulares, se encuentra esparcido en distintos lugares del Corpus luris Canonici (LII).

En otras ocasiones, sugieren la conveniencia de regular algunas materias, que los metropolitanos identifican, pero, además, proponen el sentido que ha de darse a dicha regulación, si bien no determinan los contenidos concretos de la misma, cuya especificación dejan entregada a los codificadores; es lo que sucede, por vía de ejemplo, cuando piden que se favorezca la comparecencia personal, se restrinjan las inhabilidades, la justicia se administre con el menor gasto posible o los litigantes temerarios sean reprimidos con más eficacia (XIII). ¿Cómo? No lo indican, pues solo se limita a poner de relieve la conveniencia de que se haga. No son pocas las propuestas hechas en este sentido, pues lo mismo sucede cuando piden que se regulen los casos en los que los jueces han de ser considerados inhábiles (XXII) o cuando consideran que ha de fomentarse y estimular la vida en común de los clérigos, sin sugerir vías concretas para materializar dicha propuesta (XXXI).

En la mayoría de los casos, sin embargo, los postulata sugieren reformas concretas y bien definidas: ello ocurre, solo por ilustrar algunos ejemplos, cuando proponen reducir a cinco años la visita episcopal a las diócesis (V), o a tres años la celebración de sínodos diocesanos (VI), o que los beneficios parroquiales estén adscritos a la libre disposición del obispo (XI), o la declaración de nulidad de los matrimonios por sorpresa (XLVII).

\section{Razonamiento de las propuestas}

Desde esta perspectiva, algunas propuestas llevan incorporada expresamente la o las razones que las sustentan. Es lo que sucede cuando pedían que se clarificaren con mayor precisión los requisitos del domicilio y del cuasi-domicilio, principalmente en lo que respecta a su adquisición y pérdida, lo que solicitaba "habida consideración de la movilidad actual de las personas que se desplazan de un lado a otro" (XVI), razón que justificaba también pedir que, para facilidad de la prueba de la condición civil de soltería y del estado de vida anterior en cuanto a contraer matrimonio y a recibir las órdenes sagradas, se considerare suficiente la información de testigos o la garantía de un varón probo con juramento supletorio (XVII). A veces la razón que motivaba 
la propuesta se presentaba describiendo el mal que se pretendía erradicar con la sugerencia que se hacía, lo que ocurre cuando proponían que se estatuyere que los negocios canónico-civiles terminaren de modo general mediante doble sentencia conforme, porque «aunque nuestro derecho, fundado en el derecho de Justiniano, prohíba una tercera apelación, una vez propuesta la segunda apelación a de una u otra parte, se sigue que el asunto se prolonga hasta una quinta instancia» (XXIV). Y ocasiones hubo en que las razones expuestas sirvieron para justificar varias propuestas de reforma, lo que ocurrió cuando propusieron la reducción de varios impedimentos, para lo cual expresaban los prelados que, entre otras circunstancias, era preciso tener a la vista el enfriamiento de la fe «en el tiempo actual», la mala disposición de los abogados para la aplicación de la ley y, simultáneamente, las frecuentes proposiciones de personas maliciosas al matrimonio civil o al concubinato (XLIX).

La mayoría de los postulata, sin embargo, no expresaron la razón que los motivaba, pues se limitaron a hacer la propuesta sin entrar en más detalles. Algunas de estas, en todo caso, no necesitaban mayores justificaciones, pues solo se limitaban a insistir en que se cuidare la aplicación del derecho vigente, como cuando pidieron que «hay que procurar que, por sobre todo, se observe lo que el Concilio de Trento ha decretado con suma sabiduría, es decir, que no esté permitido apelar sino de una sentencia definitiva o interlocutoria que tenga fuerza de definitiva» (XXVI); o, refiriéndose al mismo tridentino, consideraban que el precepto conciliar acerca de seleccionar el testimonio de los actores que habían de ser remitido al tribunal superior en las apelaciones con efecto devolutivo «puede conservarse» (XXIX).

\section{Estilo de las propuestas}

Es posible advertir en la formulación de los postulata de los metropolitanos españoles una variedad de estilos en su formulación. La petición que les había llegado desde Roma era que sugirieran las reformas que consideraban oportunas introducir a los cánones vigentes, por lo que, por lo general, las propuestas se formulan propositivamente, es decir, sugieren, proponen, aconsejan a los codificadores sobre la conveniencia de tal o cual reforma, pero no imponen: por ejemplo, «conviene que el Ordinario, sin perjuicio de la necesidad de impetrar el beneplácito apostólico, pueda autorizar la enajenación de los bienes de la Iglesia» (XXXVII). Otras fórmulas parecidas utilizadas en otros postulata son: "hay que empeñarse», "hay que considerar», "hay que aspirar», "es deseable», "hay que procurar que», "puede conservarse», "pueden ser prescritas las siguientes o similares normas», "habría que establecer», "conviene determinar». Propuestas propositivas que, a veces, se formulan negativamente: por ejemplo, «no sería inoportuno en el nuevo código exponer más claramente cuándo realmente las penas han sido impuestas por el derecho y señalar los casos en los que es necesaria una sentencia declaratoria del juez para la ejecución de ellas» (LV).

Un estilo todavía propositivo, pero con un acento más vehemente, se utiliza en algunas propuestas en las que se advierte una mayor necesidad de reforma según los prelados hispanos: por ejemplo, «sería totalmente conveniente - deceret omnino-, para la unidad del régimen eclesiástico, enfatizar y distinguir con suma claridad las facultades de los primados, de los metropolitanos y de los obispos en sus relaciones recíprocas y, asimismo, regular aquellas que los prelados reclaman en la actualidad respecto del capítulo y de las parroquias» (IV). Otro ejemplo, «hay suma necesidad - summa adest necessitas - de que los beneficios parroquiales estén adscritos a la libre disposición del obispo» (XI). Otras fórmulas parecidas son: «se requieren muy especialmente», "sería sumamente conveniente», "convendría muchísimo», "sería sumamente necesario», "es sumamente oportuno», "es sumamente deseable», «en todo caso debe favorecerse».

En otros casos, en cambio, las propuestas son más bien perentorias; es cierto que los prelados consultados no pueden imponer nada, pero, en ocasiones, sus sugerencias tienen un carácter más bien impositivo. Un ejemplo es el postulatum según el cual «en todo caso han de proscribirse totalmente -in omni casu proscribendi penitus - los recursos fútiles y engañosos, así como también las apelaciones de tal especie» (XXVII). Otro es la propuesta según la cual «la cohabitación con mujeres está totalmente prohibida omnino prohibeatur - a los clérigos, excepto con la madre, hermanas, sobrinas en primer grado y el auxilio de otras sin hijos, o con tías maternas de edad avanzada» (XXXIV). Las fórmulas empleadas en otras propuestas más bien impositivas son: «debe favorecerse», «deben ser clarificados», "deberá preferirse», "estará obligado», "es necesario explicar», "han de definirse», "tiene que ser muy bien regulado», "debe tenerse cuidado», "debe suprimirse», "enumérense taxativamente». Propuestas impositivas que, al igual que sucede con las propositivas, a veces se formulan negativamente: «el vicario capitular no pueda - non possit- en el plazo de tres años convocar un sínodo diocesano" (IX); y en materia de dispensas matrimoniales: «respecto de los impedimentos que se mantienen, o no se concedan dispensas o auméntense las facultades de los Ordinarios...».

Los diversos estilos literarios con que los metropolitanos hispanos formularon sus propuestas pueden darnos algunas pistas para discernir la importancia comparativa de las mismas.

\section{Importancia comparativa de las propuestas}

Como he señalado precedentemente, las propuestas formuladas por los metropolitanos españoles se presentaron todas en una larga nómina, individualizada cada una con el número de orden que le correspondía, pero sin hacer ninguna diferencia acerca de la mayor o menor importancia de las mismas o de su mayor o menor incidencia en el conjunto del ordenamiento de la Iglesia, ordenadas según la distribución de materias que se contenía en las Decretales del papa Gregorio IX. Desde esta perspectiva, simplemente formal, todas las propuestas se presentaron al mismo nivel y habrían tenido la misma densidad. Pero es, precisamente, el estilo literario utilizado en su formulación, el que permite distinguir al menos tres niveles de densidad o importancia: i) aquellas reformas que los arzobispos consideran convenientes, que corresponderían a aquellas formuladas de una manera simplemente propositiva; ii) otras reformas que consideran más importantes, para lo cual, si bien mantuvieron un estilo propositivo, agregaron elementos de 
vehemencia que mostraban la mayor importancia que le proporcionaban a la reforma que proponían; iii) finalmente, hay algunas propuestas que les resultan del todo necesarias y hasta imperiosas, que serían aquellas propuestas en un estilo literario impositivo.

Desde otra perspectiva, hay alguna sugerencia con incidencia general en el ordenamiento canónico, como ocurre con el primero de los postulata en materia procesal en el que se manifestaba la conveniencia de una ley procesal que pudiere contener de modo técnico y completo, las prescripciones comunes de una serie de procedimientos (XII). Se apuntaba, así, a una de las mayores ventajas de la codificación como proceso fijador del derecho, al proporcionar reglas unitarias, completas y técnicas, en nuestro caso, sobre la variedad de procedimiento que enunciaban los prelados y a los que he hecho referencia antes. Fue un postulatum cuya mayor envergadura no puede ponerse en duda por su incidencia en todo el ordenamiento canónico, si bien, su presentación externa no lo diferenciaba de los demás postulata enviados desde Toledo.

La mayoría de las propuestas, sin embargo, incluso aquellas que se mantuvieron en un plano de generalidad, no diferían unas de otras, en cuanto a su importancia comparativa, desde la perspectiva meramente formal o externa de su presentación.

\section{Originalidad de algunas propuestas}

El numeroso material reunido con las respuestas del episcopado latino a la primera consulta realizada por Roma, fue sistematizado según la estructura que se había definido en el índice de materias confeccionado por los cardenales y recogido, como lo indiqué al inicio de estas páginas, en un volumen bajo la dirección del consultor Bernardino Klumper, con el título "Postulata Episcoporum in ordinem digesta». Cada uno de los registros identifica el episcopado autor de la propuesta: cuando era única, es decir, no era compartida con otros episcopados, al pie del respectivo registro aparece solo el nombre del episcopado autor de la misma; pero cuando la misma proposición era hecha por diversos episcopados, el pie del registro se identifican todos ellos.

Una mirada general a las propuestas hechas desde España, por ejemplo, en materia procesal muestra una gran originalidad en las mismas. En efecto, en materia procesal Klumper recoge 15 propuestas de los metropolitanos españoles, de las cuales solo una es compartida con otro episcopado, de manera que la mayoría de los postulata españoles son originales. La única propuesta compartida lo fue con el obispo de Montauban, en Francia, en la que los prelados hispanos pedían que se hiciere obligatoria la institución de un juez instructor distinto del juez sentenciador, de lo que trataba la instrucción de la S. Congregación de Obispos y Regulares, de 11 de junio de 1880, al tiempo que algunas de sus prescripciones debían ser clarificadas y complementadas (XII). Más aún, hay algún título en sede procesal en el que la mayoría de las propuestas llegadas a Roma provenían de España. Ello ocurre con el título III, "De foro competenti», en que dos de las tres proposiciones episcopales recogidas, corresponden a las de los metropolitanos españoles, en concreto, la propuesta en la que se pedía la interpretación de la regla "actor sequitur forum rei» en la forma que ellos sugerían
(XV). ${ }^{64}$ Y la propuesta en que pedían que se indicaren con acuciosidad los negocios en los que se pudiere aplicar la prórroga de jurisdicción (XVIII). ${ }^{65}$ En otro orden de materias, fue también única la propuesta de que tenían que ser delimitadas la fuerza, el valor y las condiciones de la cláusula que hacían nulas las costumbres futuras contra cualquier ley (III), ${ }^{66}$ si bien no fue la única propuesta en lo que a costumbre se refería. También fue única la propuesta de que sería muy conveniente que se otorgaren las máximas facilidades para la creación de alguna congregación de varones con votos simples que se asignare al servicio de los sacerdotes (XXXII). ${ }^{67}$

Otras sugerencias hispanas, en cambio, fueron compartidas con otros episcopados: ello ocurre, por ejemplo, con lo referido a la reducción de ciertos impedimentos matrimoniales (XLV), en los que se produjo un amplio consenso entre los distintos episcopados, pues se trataba de una experiencia más bien transversal. Otro tanto sucedió con la necesidad de la promulgación de las normas en un periódico oficial (I). ${ }^{68}$

\section{Destino de las propuestas}

Diverso fue el destino de los postulata hispanos. Aquellas que fueron formuladas en forma general, como la primera de las propuestas procesales, se vieron acogidas en el Codex luris Canonici. Como ésta proponía que en el nuevo texto se contuviere de modo técnico y completo las prescripciones comunes de una serie de procedimientos, estaba en perfecta sintonía con lo que se pretendía con la empresa codificadora que empezaba a acometer la Iglesia, por lo que era natural que ella se viera satisfecha en el texto aprobado.

Otras sugerencias igualmente genéricas, pero referidas a materias específicas, también fueron satisfechas en el código, toda vez que las diversas medidas decididas en el Codex respecto de aquéllas satisfacían, al menos en parte, las pretensiones españolas. Es lo que sucedió, por ejemplo, con la propuesta genérica de que «la justicia debe administrarse con el menor gasto posible» (XIII), materia que el código reguló al tratar de los aranceles de tasas hechos por el concilio provincial o por los obispos reunidos en conferencia, en los que debían fijarse, entre otras, las costas judiciales y la retribución que por sus servicios debían ser abonadas a los abogados y procuradores (can. $1909 \S 1$ ), de manera que si los abogados y procuradores pactaban sobre emolumentos excesivos o sobre una parte de la cosa en litigio, lo que les estaba prohibido (can. $1665 \S 1$ ), podían ser castigados con multa, y el abogado podía ser suspendido de su oficio (§ 2). Además, el código expresamente reguló el patrocinio gratuito y la disminución de las costas judiciales (can. 19141916). ¿Era esto en lo que pensaban los prelados españoles al hacer su propuesta? No es posible saberlo a la luz de la sola lectura de sus postulata, pero lo que es cierto es que, al menos en parte, el postulatum español fue acogido.

\footnotetext{
${ }^{64}$ Codex 1905, 266.

65 Ibíd.

66 Codex 1905, 19.

67 Codex 1905, 25.

68 Lo mismo postularon los padres de la provincia de Holanda, el arzobispo de Guatemala, los padres de la provincia de Ruan en Francia, los de la provincia de Chile y los de la provincia de Besançon en Francia. Codex 1905, 16.
} 
En otras ocasiones, las propuestas genéricas formuladas desde España se vieron cumplidamente acogidas. Es lo que ocurrió, por ejemplo, con la propuesta de que, habida consideración de la movilidad que se vivía por las personas que se desplazaban de un lado a otro, debían ser clarificados con mayor precisión los requisitos del domicilio y del cuasidomicilio, principalmente en lo que respecta a su adquisición y pérdida (XVI). El código abordó específicamente el tema en el canon 92 que precisó como se adquiría el domicilio - residencia en una parroquia o cuasi-parroquia, o por lo menos en una diócesis, vicariato apostólico o prefectura apostólica, siempre que la residencia, o vaya acompañada de la voluntad de permanecer en aquel lugar perpetuamente, si no hay causa que lo impida, o se prolongue por un decenio completo ( $\S 2$ ) - o se adquiría el cuasi-domicilio - residencia como se acaba de indicar, que vaya junta con la intención de permanecer en el lugar por lo menos la mayor parte del año, si no hay causa que lo impida, o que se prolongue, de hecho, a la mayor parte del año (§ 2)-; y según el canon 95, uno y otro se perdían por el hecho de abandonar el lugar con ánimo de no volver. De esta manera, la propuesta hispana quedó del todo satisfecha en el Codex.

Hubo también propuestas específicas que fueron acogidas, por ejemplo, la referida al impedimento de parentesco espiritual, respecto del cual el código, tal como se solicitaba desde España (XLV), dispuso que «solamente el bautizante y el padrino contraen por el bautismo parentesco espiritual con el bautizado» (can. 768, 1079). Lo mismo sucedió con la pretensión de que se suprimieran los matrimonios por sorpresa (XLVII). No quiero con esto decir que fueran precisamente las sugerencias españolas las que dieran origen a los precisos cánones codiciales; de hecho, la reducción del parentesco espiritual no era original de los prelados españoles, pues ellos se habían inspirado en el Concilio Vaticano I. Pero no se puede negar que en los dos ejemplos que he proporcionado era clara la consonancia de los prelados de España con los codificadores.

Por el contrario, hubo otras peticiones que no fueron acogidas, como ocurrió con la que pretendía que se introdujere y regulare el recurso ordinario de queja, a favor de los casos en los cuales fuere denegada la apelación y casos similares (XXVIII). O con la de que se suprimiera el impedimento de parentesco legal $(X L V g)$, pues este se mantuvo en el Código, si bien de manera notablemente simplificada (can. 1080).

\section{A MODO DE CONCLUSIÓN}

Se advierte de la lectura de las propuestas españolas a Roma para reformar el derecho canónico a los inicios de su primera codificación, por una parte, la formación jurídica de algunos prelados, no solo en los cánones, sino también en el derecho del Estado, como Marcelo Spínola, arzobispo de Sevilla, que era abogado y, antes de ser ordenado presbítero, había ejercido la abogacía. Por su parte, algunos de los obispos sufragáneos que debieron ser consultados habían escrito libros sobre materia canónica, como Francisco Gómez de Salazar y Lucio de Villega, obispo de León, sufragáneo de Burgos; ${ }^{69}$ y José Cadena y Eleta, obispo de Segovia

69 Gómez de Salazar 1871, 1883, 1875. Gómez de Salazar; De la Fuente 1868,1880. y sufragáneo de Valladolid. ${ }^{70}$ Las obras de ambos prelados se centraban en el derecho canónico procesal - Cadena y Eleta había escrito un Proyecto de Código Procesal Canónicopor lo que no es de extrañar el número de propuestas en dicha materia formuladas por los metropolitanos, las que alcanzaron un tercio del total de las sugerencias hechas a Roma. $^{71}$

Pero, además, pocos años antes algunos metropolitanos que intervinieron en la confección de este informe habían obtenido de la Santa Sede que sus seminarios fuesen reconocidos como universidades pontificias, habilitadas para conferir, entre otros, los grados de licenciado y doctor en derecho canónico. Así lo habían obtenido Spinola, en Sevilla; Costa y Fornaguera, en Tarragona; y Aguirre y García, en Burgos. Contaban, así, con un grupo calificado de canonistas que podían asesorarles valiosamente en sus respuestas a Roma. No es muy difícil pensar que la ayuda de estos colegios de canonistas fuera la que permitió que los codificadores romanos se vieran enriquecidos con estos aportes peninsulares.

A lo anterior, es preciso agregar la experiencia que tanto los metropolitanos como los obispos sufragáneos habían adquirido en el gobierno de la Iglesia lo que les permitía tener no solo una mirada académica sino también práctica acerca de las reformas que necesitaba el derecho de la Iglesia.

Este conjunto mutuamente enriquecido de academia y práctica hizo que la primera participación de los metropolitanos españoles en respuesta a la invitación formulada desde Roma al inicio de las tareas codificadoras que llevarían a la promulgación del Código de Derecho Canónico de 1917, sobresaliese en el concierto de las primeras propuestas arribadas a Roma por su número, variedad, calidad general de las sugerencias y originalidad de no pocas de las mismas, mérito aún mayor si tomamos en cuenta el tiempo relativamente corto con que contaron.

\section{FUENTES}

Archivio Segreto Vaticano, Commissione Cod. Diritto Canonico, scat. 4, 6, 84.

Appendix ad Postulata Episcoporum. Typis Vaticanis, 1908. Archivio Segreto Vaticano, Commisione Cod. Diritto Canonico, scat. 6.

Benedicto XV. 1917. Constitución apostólica «Providentissima Mater Ecclesiae». Acta Apostolicae Sedis 9: 5-8.

Codex luris Canonici. Postulata Episcoporum in ordinem digesta a Rmo. P. Bernardino Klumper O. F. M. Consultore. Romae, Typis Vaticanis, 1905. Archivio Segreto Vaticano, Commisione Cod. Diritto Canonico, scat. 4.

Friedberg, A. E, ed. 1879. Corpus Iuris Canonici. Lipsiae; 1956. Graz.

Gasparri, Pedro. 1904-1905. «Circular Perlegisti (6 abril 1904)». Acta Sanctae Sedis 37: 130-131.

Mansi, Giovanni Domenico. 1927. Sacrorum conciliorum nova et amplissima collectio [...] Sacrosancti oecumenici Concilii Vaticani, 53. Arnhem (Pays-Bas) \& Leipzig.

Pio X. 1903-1904. "Motu proprio Arduum sane munus (19 marzo 1904)». Acta Sanctae Sedis 37: 549-551.

Secretaría de Estado del Vaticano. 1903-1904. "Circular Per gratum mihi (25 marzo 1904)». Acta Sanctae Sedis 36: 603-604.

\footnotetext{
70 Cadena y Eleta 1891, 1895.

71 Para la biografía y formación intelectual de los arzobispos espa-
} ñoles, ver Salinas 2019. 


\section{BibLIOgRAFÍA}

Baura de la Peña, Eduardo. 2017. «Lo spirito codificatore e la codificazione latina». Ius Ecclesiae 29 (1): 15-37.

Baura de la Peña, Eduardo, Nicolás Álvarez de las Asturias y Thierry Sol. eds. 2017. La codificazione e il diritto della Chiesa. Milano: Giuffrè Editore.

Cadena y Eleta, José. 1891. Tratado teórico-práctico de procedimientos en materia civil y criminal, I: De la jurisdicción voluntaria y del procedimiento gubernativo; II: De la jurisdicción contenciosa y del procedimiento judicial. Madrid: Imprenta de don Luis Aguado.

Cadena y Eleta, José. 1895. Proyecto de Código Procesal Canónico. Madrid: Imprenta de don Luis Aguado.

Del Paso y Delgado, Nicolas. 1874. Derecho canónico dividido en tres tratados. Granada: Librería del Editor D. José López Guevara.

Fantappiè, Carlo. 2008. Chiesa Romana e modernità giuridica I: L'edificazione del sistema canonistico (1563-1903); II: II Codex luris Canonici (1917). Per la storia del pensiero guiridico moderno 76 Milano: Giuffrè Editore.

Fantappiè, Carlo. 2011. Storia del diritto canonico e delle istituzione della Chiesa. Bologna: Società editrice II Mulino.

Fantappiè, Carlo. 2017a. «Dal paradigna canonistico classico al paradigna codificatorio». En La codificazione e il diritto della Chiesa, ed. Eduardo Baura, Nicolás Álvarez de las Asturias, Thierry Sol, 3-34. Milano: Giuffrè Editore.

Fantappiè, Carlo. 2017b. «Dal paradigna canonistico classico al paradigna codificatorio». Ius Ecclesiae 29 (1): 39-50.

Fantappiè, Carlo. 2018. «El código de 1917 en la historia del derecho de la Iglesia». Anuario de Derecho Canónico 7: 41-55.

Gómez de Salazar, Francisco. 1871. Manual eclesiástico. Madrid: Librería Miguel Olamendi.

Gómez de Salazar, Francisco. 1883. Instituciones de derecho canónico. 2a edición. 3 vols. Madrid: Imprenta de Alejandro Gómez Fuentenebro.

Gómez de Salazar, Francisco. 1875. Tratado de las censuras ecle siásticas con arreglo a la constitución Apostolicae Sedis expedida el 12 de octubre de 1869. Madrid: Imprenta de A. Gómez Fuentenebro.
Gómez de Salazar, Francisco y Vicente de la Fuente. 1868. Tratado teórico-práctico de procedimientos eclesiásticos. Madrid: Imprenta y Librería de D. Eusebio Aguado.

Gómez de Salazar, Francisco y Vicente De la Fuente. 1880. Lecciones de disciplina eclesiástica y suplemento al tratado teórico-práctico de procedimientos eclesiásticos. Madrid: Imprenta de Alejandro Gómez Fuentenebro.

Gómez-Iglesias Casal, Valentín. 2017a. «De la centralidad de la ley al primado de la persona en el derecho de la Iglesia. Historia y perspectivas canónicas en el centenario del Código de 1917». Ius Canonicum 57 (114): 495-568.

Gómez-Iglesias Casal, Valentín. 2017b. «Acerca de la trascendencia histórica de la iniciativa de san Pío $X$ de elaborar un Código de Derecho Canónico». Ius Ecclesiae 29 (1): 51-76.

Guzmán Brito, Alejandro. 2005. «El origen y desarrollo de la idea de codificación del derecho». En El Código Civil de Chile (1855-2005). Trabajos expuestos en el Congreso internacional celebrado para conmemorar su promulgación, ed. Alejandro Guzmán Brito, 43-99. Santiago: Lexis Nexis.

Juseu y Castanera, Juan. 1899. Instituciones de derecho canónico general y particular de España. Valencia: Establecimiento Tipográfico Domenech.

Lo Castro, Gaetano. 2017. «Il compito della scienza giuridica nell'epoca della codificazione». Ius Ecclesiae 29 (1): 77-90.

Llobell, Joaquìn, Enrique De León y Jesús Navarrete. 1999. II libro «De processibus» nella codificazione del 1917. Studi e documenti. Milano: Giuffrè.

Manjón y Manjón, Andrés. 1900. Derecho eclesiástico general y español. Granada: Imprenta de las Escuelas del Ave María.

Salinas Araneda, Carlos. 2018. «Obispos de Chile y España en la codificación canónica de 1917: los postulata sobre el matrimonio». Teología y Vida 59 (1): 59-84.

Salinas Araneda, Carlos. 2019. "Los arzobispos de Chile y España en el proceso codificador del derecho canónico de 1917: una historia compartida». Boletín de la Academia Chilena de la Historia 84 (127): 97-154.

Vetulani, A. 1942. "Codex luris Canonici». Dictionnaire de Droit Canonique. Paris: III. 